\title{
Die vraag na die noodsaaklikheid van 'n eietydse belydenis: Nuwe Testamenties en hermeneuties beoordeel
}

\author{
G M M Pelser \\ Departement Nuwe-Testamentiese Wetenskap (Afd A) \\ Universiteit van Pretoria
}

\begin{abstract}
The question regarding the need for a contemporary creed: Argued from a New Testament and hermeneutical perspective.

As indicated in the tille of this study, what is in essence at issue here is the question as to whether there is a need for a creed to be contemporaneous wilh the day and age the church finds itself in. It is argued that to produce a creed in accordance with current hermeneutical insights is much more difficult than the way in which the existing creeds were created. It is therefore further argued that, for a creed to function as it ought to, it should in the first place be the result of an interpretation of the Biblical text(s) on the basis of current hermeneutical theory and practice, and in the second place be a means for expressing one's faith in a meaningful way in every life situation or faith experience. To this end a creed should be contemporaneous with each and every situation encouniered by the individual believer or community of faith.
\end{abstract}

\section{VOORAF OPMERKINGS}

Dit is algemene kennis dat die belydenisse en die belydenisskrifte van die kerk histories kontingente dokumente is wat elkeen in 'n bepaalde situasie en om 'n bepaalde rede ontstaan het. Hierby is hulle inhoude en die wyse waarop dit geformuleer is, verteenwoordigend van die eksegese en teologie van die tyd en "konfessionele" omgewing waarin hulle ontstaan het. Dit maak hulle vanselfsprekend "gedateerd", aangesien eksegese en teologie, maar ook kerk en wêreld sedert hulle ontstaanstyd ingry- 
pend verander het. Die gevolg hiervan is dat hierdie dokumente tot op groot hoogte nie meer beantwoord aan die doel waarvoor hulle daargestel is nie, naamlik dat hulle die verwoording moet wees van die geloofsoortuigings en -ervarings ook van die kerk van vandag. Dit wil sê die gelowiges in die teenswoordige geloofsgemeenskap moet dit wat in hierdie dokumente vervat is, net so belydend kan uitspreek, hulle daardeur net so aangespreek voel en daarvolgens moet kan lewe op dieselfde wyse as die geloofsgemeenskap(pe) wat hulle tot stand gebring het. Hierdie dokumente gaan dus in 'n sekere sin mank aan ' $n$ funksieverlies.

Op die vraag wat gedoen behoort te word in die lig van hierdie gedateerdheid van die dokumente word volgens my waarneming in hoofsaak drie standpunte gehuldig. Eerstens is daar dié wat oordeel dat aangesien die belydenisse historiese dokumente is, daar nie aan hulle verander mag word nie, maar dat dit wel in die lig van nuwere teologiese insigte en veranderde omstandighede "geïnterpreteer" moet word. Waar hulle dus nie meer "reg" bely nie, moet hulle deur middel van interpretasie "in lyn" gebring word. Tweedens is daar die standpunt dat die belydenisse steeds aangepas behoort te word sodat hulle "eietyds" sal wees en dus telkens die funksie sal vervul waarvoor hulle bedoel is. Derdens word die gedagte voorgestaan dat in pas met die stand van die eksegese en teologie van die kerk en na die eis van omstandighede ' $n$ nuwe belydenis opgestel behoort te word wat bestaande leemtes sal uitskakel en sal beantwoord aan wat tans as vereiste daarvoor gestel mag word.

Soos deur die titel hierbo aangedui, is dit my voorneme om met hierdie studie aan die hand van die Nuwe Testament te probeer uitmaak of daar 'n behoefte aan 'n eietydse kerklike belydenis bestaan. Of om dit miskien duideliker te stel, dit gaan oor die vraag of daar ' $n$ aanduiding in die Nuwe Testament is dat ' $n$ belydenis aan die vereiste van eietydsheid moet voldoen; ongeag of dit 'n verandering van die bestaande belydenisse of die daarstelling van 'n nuwe belydenis sou behels. Soos reeds uit die eerste paragraaf hierbo afgelei kon word, is die vraag na 'n eietydse belydenis na my oordeel tweeledig van aard: enersyds vra dit of 'n belydenis die jongste resultate moet weerspieël van die eksegese van die teks(te) waarop dit gebaseer is; andersyds vra dit of ' $n$ belydenis uitdrukking moet wees van die geloofsverstaan van die geloofsgemeenskap wat dit hier en nou bely. Wat so pas gesê is, raak natuurlik nog net die vraag na die eis dat 'n belydenis vir elke tyd relevant moet wees. Dit raak nie die vraag of die kerk enigsins behoefte aan 'n belydenis het nie en ook nie die vraag of ' $n$ belydenis as ' $n$ min of meer vas geformuleerde grootheid nog moontlik is in die lig 
van die ontwikkelings op die gebied van teksteorie en interpretasie nie. Hieraan sal ook in hierdie studie aandag gegee word.

Wat gou duidelik word by 'n poging om vanuit die Nuwe Testament op die vraag na die noodsaaklikheid van eietydsheid te antwoord, is dat dit nie as 'n debatspunt onder die vroegste geloofsgemeenskappe gedien het nie en dat daar gevolglik nie 'n direkte antwoord uit die Nuwe Testament af te lees is nie. Die veronderstelling met hierdie studie is daarom ook nie om na 'n direkte antwoord te soek nie. Dit is eerder om te probeer uitmaak of daar op grond van Nuwe-Testamentiese gegewens sekere afleidings gemaak kan word wat bepalend of van nut kan wees vir die beantwoording van die vraag. Wat vir my nietemin aksiomaties blyk te wees, is dat gesien die feit dat die Nuwe Testament tot op groot hoogte as bron en basis vir die belydenis van die kerk gedien het, dit steeds 'n deurslaggewende rol behoort te speel by die beantwoording van die vraag na die wenslikheid al dan nie van 'n eietydse belydenis. Verder blyk dit dat ' $n$ mens tevergeefs soek vir die behandeling van hierdie onderwerp in studies op die Nuwe-Testamentiese vakgebied. Dit beteken dat daar in sekondêre literatuur bykans geen klankbord bestaan waarteen jy jou standpunt in verband met hierdie vraag kan toets nie.

\section{BELYDENIS IN DIE NUWE TESTAMENT}

Dit is met goeie reg dat beweer kan word dat die kerk van die begin af ' $n$ belydende kerk was (Wirsching 1980:487). Dit kan naamlik duidelik afgelei word uit die feit dat daar in die Nuwe Testament 'n ryke verskeidenheid kort credo's en belydenisagtige formulerings voorkom wat almal in 'n mindere of meerdere mate onder die noemer belydenis tuisgebring kan word. Klaarblyklik was hierdie "belydenisse" minstens gedurende die vroegste stadia van die geskiedenis van die kerk(e) nog nie bedoel om soos later ' $n$ identiteitsvormende of na buite afgrensende funksie te vervul of as norm vir die regte leer te dien nie. Elkeen van hulle was in een of ander vorm 'n geloofsresponsie op die Christus-kerugma soos dit deur die verskillende vroegste geloofsgemeenskappe verstaan is. Hulle moet daarom gesien word as spontane verwoordings van die verskillende geloofservarings van hierdie gemeenskappe soos wat daar aan so 'n verwoording behoefte ontstaan het in die verskillende Sitze im Leben van die geloofslewe van hierdie gemeenskappe. Dit is ook om hierdie rede dat daar in die Nuwe Testament soveel verskillende tipes belydenisse geïdentifiseer kan word. 
Volgens Köster (1971:191) was twee faktore daarvoor verantwoordelik dat hierdie vroegste geloofsgemeenskappe soveel verskillende geloofsantwoorde op die verkondiging gegee het. Enersyds het die onderskeie religieuse en kulturele agtergronde van die bekeerdes daartoe bygedra, andersyds is dit veroorsaak deur die meerduidigheid van die historiese werk en lotgevalle van Jesus. Die verskeidenheid is dus nie net toe te skryf aan die meervoudige wyse waarop daar oor die Christusgebeure gedink en verkondig is nie, maar ook aan die denkkategorieë waarvan daar vanuit die Joodse of die Grieks-Romeinse wêreld vir die formulering van hierdie geloofsantwoorde gebruik gemaak is. Die begin van die geskiedenis van die Christelike belydenis was volgens Köster (1971:194) dus net so veelvoudig as die kulturele en religieuse pluralisme van die Hellenistiese en Romeinse wêreld. Wat verder opvallend is, is dat hierdie vroegste geloofsgemeenskappe dit klaarblyklik nie nodig geag het om 'n meer omvattende of gesistematiseerde belydenis daar te stel soos later in die geskiedenis van die kerk gebeur het nie. In hierdie vroegste stadia word nog net in kort formulerings bely, terwyl 'n meer uitgebreide belydenis eers by Ignatius (Smi I:1-2) aangetref word. In verband met die genoemde verskeidenheid van belydenisse asmede die ontbreking van 'n meer omvattende belydenis maak Wengst (1984:398) tereg die volgende opmerking: "Sie haben wohl vor allem die Funktion, daß sich die Glaubenden ihres Glaubens vergewissern, indem sie in ihren Erfahrungen aussprechen, was sie gemeinsam glauben. Das erklärt vielleicht ihre Vielfalt und das Fehlen einer Tendenz zur Vereinheitlichung und Normierung."

Oor die voorkoms en aard van die genoemde belydenisse is daar, afgesien van enkelondersoeke wat oor bepaalde belydenisse of liedere gedoen is, vroeër reeds betreklik uitvoerige studies onderneem. Om 'n indruk te kry van die verskeidenheid van Sitze waarin en wyses waarop die vroegste geloofsgemeenskappe deur middel van hierdie belydenisse uiting aan hulle geloof gegee het, kan maar net weer gekyk word na die werk wat veral Wengst $(1967,1984)$ en Deichgräber $(1967,1983)$ in hierdie verband gedoen het. Hieruit blyk hoe lewenskragtig en gevarieerd daar belydend, lofprysend en verkondigend uitdrukking gegee is aan die betekenis van die Christusgebeure asmede die baie fasette van die geloofsbelewing van hierdie gemeenskappe. Om net maar van die bekendstes te noem, kan na die volgende verwys word: himnes en eulogieë tot eer van God (Luk 1:46-55, 68-79; Rom 11:33-36; 2 Kor 1:3-4 Ef 1:3-14; Kol 1:12-14; 1 Pet 1:3-5;) en van Christus (Fil 2:6-11; Kol 1:15-20; 1 Tim 3:16; Heb 1:3; 1 Pet 2:22-24;); Christologiese formules soos die belydenis dat Jesus 
die Seun van God is (Rom 1:3-4; 1 Joh 4:15), dat Hy Here is (Rom 10:9; 1 Kor 8:6; 12:3; Fil 2:11); soteriologiese formules soos dat Jesus in die dood "oorgegee is vir ons/julle" (Mark 10:45; Rom 4:25; 8:32; Gal 1:4; 2:20; Ef 5:2,25), dat Hy "gesterf het vir ons/julle" (Rom 5:6,8; 14:15; 1 Kor 8:11; 2 Kor 5:14-15; 1 Tess 5:10; 1 Pet 3:18), dat Hy. "opgewek" is (Rom 4:25; 10:9; 1 Kor 15:4; 2 Kor 5:15), dat sy dood 'n "soendood" (Sühnetod) was (Rom 3:25; 1 Joh 2:2) en "Versoening" (Versöhnung, Rom 5:10; 2 Kor 5:18-19) bewerkstellig het. Uit hierdie studies blyk verder duidelik dat die onderskeie belydenisse funksioneel in hulle onderskeie Sitze aangewend is en nie leerstellig nie. Hierdie feit word ook deur Conzelmann bevestig wanneer hy daar-

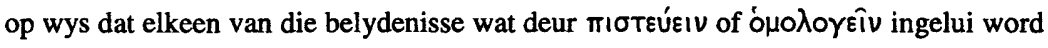
(eersgenoemde tipeer hy as credo en laasgenoemde as homologie), 'n bepaalde faset van die Christus-gebeure verwoord. Volgens hom verwoord eersgenoemde iets van die heilswerk van Christus, terwyl hy laasgenoemde verklaar as akklamatoriese aanroeping van die verhoogde Here, waartoe behoort die "Proklamation" van Christus "vor der Welt" (Conzelmann 1968:82; kyk ook Conzelmann \& Lindemann 1980:110). 'n Opvallende kombinasie van hierdie twee vorme vind ons in Paulus se bekende

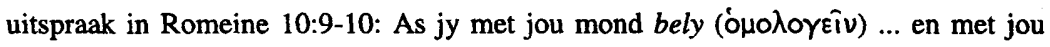

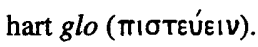

In 'n vorige artikel (Pelser 1997) het ek probeer aantoon dat Paulus nie gehuiwer het om die geloofsbelydenisse of liedere wat deur hom benut is, te verander of aan te pas met die doel om dit bruikbaar te maak vir die uitdra van die evangelie soos hy dit verstaan het nie. Ek het hieruit die gevolgtrekking gemaak dat hy hierdie belydenisse nie beskou het as leerstukke wat onveranderd gelaat en as voorskrywend vir sy verkondiging of "teologie" hanteer moes word nie. Ek het ook met instemming gewag gemaak van die opmerkings van Bultmann, Bauer en Dunn dat daar in die eerste eeu n $\mathrm{C}$ beslis nog nie sprake was van 'n regula fidei of van "regsinnigheid" in die sin waarin dit later verstaan is nie. Hierdie feit word onder andere ook deur die volgende opmerking van Köster (1971:191) ondersteun: "Am anfang der Geschichte der christlichen Theologie standen weder ein bestimmtes Dogma oder Glaubensbekenntnis; noch läßt sich die Entstehung der verschiedenen Formen häretischer Entwicklungen in der frühen Geschichte der Christenheit als Abirrung von einem ursprünglichen und rechtglaubigen Glaubensbekenntnis begreifen (kyk ook Wengst 1967:197-198). Ek het verder daarop gewys dat navorsing uitgewys het dat dit selfs 
in die tweede eeu nog nie 'n uitgemaakte saak was wat onder die begrippe "ortodoks" en "dwaalleer" verstaan moes word nie (Pelser 1997:1234-1235; kyk ook Hultgren 1994:2-4). Om dit in die woorde van Köster (1980:502) te stel, daar het ook nog nie in die tweede eeu 'n "allgemeingültige Formulierung des Glaubensbekenntnisses" bestaan nie. Wat van Paulus geld, kan met reg ook van die meeste ander dokumente van die Nuwe Testament gesê word. Ouere vorme is dikwels nuut geïnterpreteer en in belydenisse geïnkorporeer wat oorspronklik tot 'n ander grondtipe behoort het. So kan byvoorbeeld verwys word na die outeurs van Kolossense (1:15-20) en Efesiërs (2:14-18) wat albei bestaande himnes en tradisiestukke gebruik en aangepas het om dit te laat help uitdrukking gee aan die betekenis van die Christus-gebeure soos húlle dit verstaan het.

Hieruit het veral twee dinge duidelik geword in verband met die begrip belydenis in die vroegste kerk. Enersyds is dit 'n bevestiging van wat reeds hierbo opgemerk is, naamlik dat 'n belydenis beskou is as iets wat altyd "funksioneel" moes wees. Dit hou in dat 'n mens met betrekking tot hierdie periode streng gesproke nog nie van 'n "belydenis" behoort te praat nie, maar slegs van die "gebeure" van bely soos dit deur die verskillende situasies van die geloofslewe as uitdrukkings van die geloofsverstaan en -ervaring genoodsaak is. Dit beteken dat die term "belydenis" in hierdie geval in die strengste sin van die woord semanties as 'n gebeure-woord en nie as 'n objek verstaan is nie. In hierdie verband is Conzelmann volkome gelyk te gee wanneer hy hom soos volg uitlaat oor die dinamiek en die funksionaliteit wat daar klaarblyklik vir die vroegste Christene in hulle belydenisse opgesluit gelê het: "Das Bekenntnis fordert nicht nur eine Entscheidung. Es hat die Kraft, sie selbst herbeizuführen" (Conzelmann 1968:82).

Met sy genoemde uitspraak in Romeine 10:10 gaan Paulus in werklikheid nog verder wat betref die dinamiek en funksionaliteit van 'n belydenis. Hy ken aan die belydenis dat Jesus "die Here is" en dat God Hom "uit die dood opgewek het", as sodanig verlossende krag toe: "Met die hart glo ons, en ons word in die regte verhouding met God gestel; met die mond bely ons, en ons word gered". (Dit stem in 'n sekere sin ooreen met die krag wat hy meen daar in die evangelie gesetel is wanneer

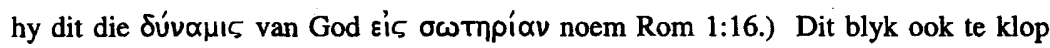
met die oortuiging wat veral in die "taalhandelingsteorie" gehuldig word dat mense in antieke tye taal nie gesien het as wyse van betekenisoordrag nie maar as krag, asmede met hierdie teorie se algemene siening oor taal, naamlik dat "an utterance means what 
it does, not what it says" (kyk Fowler 1991:48). Andersyds dui die resultate van die ondersoeke na die ontstaan en geskiedenis van die belydenisse van die vroegste kerk op die "eietydsheid" van hierdie belydenisse, dit wil sê op die feit dat hulle as herformuleerbaar beskou is en inderdaad dikwels herformuleer is aan die hand van elke nuwe insig en behoefte in elke nuwe situasie. Só kon dit telkens weer word tot 'n nuwe uitdrukking van 'n eksistensiële geloofsbelewenis by die gelowige of dien as 'n nuwe verwoording van die essensie van die evangelie. Met ander woorde 'n belydenis het alleen bestaansreg gehad solank dit dít wat dit verwoord het tot 'n werklikheid laat word het, dit wil sê solank dit mense tot 'n bepaalde geloofsbelewenis kon bring of vir hulle as die verwoording van 'n geloofsbelewenis kon dien. 'n Mens kan immers alleen weet wat jy ervaar as jy dit in woorde kan uitdruk.

Vir hoe lank die belydenisse van die vroegste geloofsgemeenskappe hierdie dinamiese en funksionele karakter behou het, is moeilik om te sê. As 'n mens egter in ag neem watter afname van die spontane en charismatiese en die daarmee gepaardgaande toename in institusionalisering daar reeds in die latere dokumente van die Nuwe Testament te herken is, kan aanvaar word dat sake reeds teen die einde van die eerste eeu merkbaar moet verander het. Köster, hoewel hy nie aandui van wanneer af dit gebeur het nie, oordeel dat in die latere ontwikkeling van die teologie die geloofsantwoorde van die vroeëre tye tot gefikseerde oorgelewerde formules geword het en opgehou het om "ein zeitgemäßer und gültiger, kulturell bedingter Ausdruck des Glaubens zu sein; statt dessen dienen sie nun als Ersatz für die in der Vergangenheit liegende Offenbarung im geschichtlichen Jesus" (Köster 1971:191). So het hierdie geloofsantwoorde en -simbole die eintlike voorwerp van die geloof, naamlik die Christusopenbaring, verplaas en self tot geloofsobjek geword. Dit is 'n opmerklike en bekende feit dat terwyl die Apostolicum nog met goeie reg as 'n geloofsimbool bestempel kan word en klaarblyklik hoofsaaklik so gefunksioneer het, die Niceno-Constantinopolitanum en in nog groter mate die Atanasianum 'n oorwegend leerstellige en dwaalleer bestrydende karakter gekry het.

Indien die waarnemings hierbo in verband met belydenis in die Nuwe Testament korrek is, moet 'n mens aflei dat die gedagte van 'n belydenis wat as 'n sisteaties-leerstellige en dwaalleer bestrydende entiteit 'n soort onafhanklike bestaan voer, soos in die geval van die latere kerklike belydenisse en belydenisskrifte, vir die geloofsgemeenskappe van die Nuwe-Testamentiese periode 'n vreemde verskynsel sou wees. Omdat, soos reeds aangetoon, elke belydenis of belydenisformule gedurende 
hierdie vroeë periode gerig was op die situasie waardeur dit genoodsaak is of 'n uitdrukking was van 'n geloofservaring, was die intensie in die eerste plek klaarblyklik nie om 'n belydenis daar te stel nie. Daar is telkens spontaan en met oorgawe bely en 'n belydenis het alleen bestaansreg gehad as dit telkens weer en elke keer opnuut uitdrukking van die geloofsbelewing van die geloofsgemeenskap was. In die lig hiervan blyk daar voldoende rede te wees om die vroegste geloofsgemeenskappe, sonder om hulle te idealiseer, in die volste sin van die woord te tipeer as "belydende" kerke, en daarom beslis nie as "belydenis"-kerke nie.

\section{BELYDENIS AS VERWOORDRING VAN DIE GETUIENIS VAN DIE SKRIF}

Beweeg 'n mens nou na die na-Nuwe-Testamentiese situasie(s) dan is die eerste saak wat die aandag vra die vraag na wat as bron vir 'n kerklike belydenis moet dien. Hierop sal tradisioneel kwalik 'n ander antwoord gegee word as dat dit die Skrif is, en daarom leef die kerk dan ook in die oortuiging dat dit wat in die belydenisse en belydenisskrifte van die kerk verwoord is, nie alleen op die Skrif gegrond is nie maar ook in ooreenstemming met die getuienis van die Skrif is. Verder is dit in die meeste gevalle die veronderstelling dat die Skrif in totaliteit as bron of basis vir die kerk se belydenis dien en nie slegs seleksies daaruit nie, hoewel natuurlik nie elke onderdeel van die Skrif in die belydenisse of belydenisskrifte neerslag gevind het nie. Hierdie veralgemenende benadering tot die Skrif as bron van die belydenis berus op die tradisionele Skrifbeskoulike standpunt dat die Skrif enersyds 'n eenheid vorm en andersyds in essensie eenstemmig is. Dit wil sê die Skrif is en word hanteer as sou die verskillende onderdele daarvan op een of ander wyse saamsluit en die verskillende stemme wat daarin gehoor word, elkeen op 'n eie wyse oor dieselfde saak getuig en uiteindelik met mekaar harmoniseerbaar is. In die lig van die verskeidenheid in die Skrif, en by name die Nuwe Testament wat die sterkste in die kerklike belydenisse figureer, is so ' $n$ veralgemenende of totaliteitsbenadering tot die Skrif egter om begryplike en bekende redes net nie meer 'n aanvaarbare opsie vir 'n hedendaagse krities-wetenskaplike Skrifbeskouing en -hantering nie.

Natuurlik moet in hierdie verband daarop gewys word dat verskeidenheid as sodanig nie 'n probleem hoef te wees nie, aangesien verskeidenheid nie noodwendig uiteenlopendheid of teenstrydigheid hoef te impliseer nie. Verskillende uitdrukkings 
van gelowige selfverstaan kan naamlik naas mekaar gehandhaaf word en in eie reg vir verkondiging en teologie diensbaar wees. Wat egter wel 'n probleem is, is die bekende feit dat daar in beide die Ou en die Nuwe Testament religieuse gedagtes voorkom wat eenvoudig nie met mekaar harmoniseerbaar is nie en mekaar selfs weerspreek. Trouens daar is in die Nuwe Testament min religieuse temas of konsepte waaroor die dokumente van die Nuwe Testament dit met mekaar eens of volkome eens is, sy dit op die gebied van die Christologie, pneumatologie, soteriologie, ekklesiologie, sakramentsteologie of eskatologie. Iets van hierdie toedrag van sake word soos volg deur Wengst (1967:195) verwoord in verband met die christologiese formules wat deur hom ondersoek is: "Die erarbeiteten Formeln lassen eine Mehrzahl christologischer Konzeptionen erkennen, die nebeneinander stehen und sich nicht in ein einziges Entwicklungschema einordnen lassen."

Hierdie verskeidenheid is egter tradisioneel nie by die opstel van die kerklike belydenisse en belydenisskrifte in aanmerking geneem of verdiskonteer nie. Die kerk het. naamlik enersyds gedagtes geharmoniseer wat vir die kerk harmoniseerbaar voorgekom het, maar streng gesproke nie harmoniseerbaar was nie, en andersyds net dít geselekteer wat as teologies aanvaarbaar of "ortodoks" beskou is. As voorbeeld van harmonisering kan verwys word na die wyse waarop in Sondag 12, Vraag en Antwoord 31 van die Heidelbergse Kategismus uitsprake in verskillende Bybelse dokumente onproblematies saamgevoeg is om by die bekende Christologiese leerstuk van die munus triplex uit te kom. En dat minstens die Protestantse deel van die kerk deur die klem wat gelê word op die regverdigingsleer en die soteriologie waarop dit gebaseer is, selektief baie meer prominensie aan Paulus verleen het as aan ander NuweTestamentiese getuienisse en selfs die historiese Jesus, kan beswaarlik ontken word. Hierdie harmonisering en selektering het tot gevolg gehad dat ongelyksoortige gedagtes saamgevoeg geraak het en belangrike alternatiewe geloofsoortuigings van sommige van die vroegste geloofsgemeenskappe nie aan die bod gekom het nie. Van hierdie twee wyses van doen, naamlik die harmonisering van onharmoniseerbares en die seleksie van wat op ' $n$ bepaalde stadium as teologies aanvaarbaar beskou is, is laasgenoemde beslis meer verdedigbaar as eersgenoemde, aangesien dit minstens 'n bewuste teologiese keuse vir hierdie of daardie standpunt verteenwoordig. Dit alles beklemtoon egter net weer die dilemma waarin die kerk verkeer wanneer gepoog moet word om te midde van die verskeidenheid in die Skrif 'n verteenwoordigende belydenis of ' $n$ gesistematiseerde belydenisskrif op te stel met die vereiste dat dit in 
ooreenstemming met die "Skrif" moet wees. Dit is natuurlik die kerk se goeie reg om 'n keuse te maak, en dat dit telkens gebeur het en sal gebeur, moet as onvermydelik en vanselfsprekend beskou word.

Dit bring egter die vraag na die legitimiteit of gefundeerdheid van die kerk se keuse na vore. As konkrete voorbeeld kan verwys word na 'n element van die kerklike belydenis wat in die jongste tyd taamlik prominent onder bespreking gekom het, 'n debat wat deur sommiges met aansienlike onbehae beleef is, naamlik die belydenis van die maagdelike verwekking van Jesus. Soos bekend, kan hierdie belydenis op die getuienis van slegs één, uiters twee, van die Nuwe-Testamentiese dokumente gebaseer word, terwyl die res blykbaar daar óf niks van geweet het nie of van oordeel moet gewees het dat Jesus op dieselfde wyse as enige ander mens verwek is. Klaarblyklik het die kerk in hierdie verband geoordeel dat die swye van die ander dokumente instemming met die Lukaanse berig impliseer, so asof hulle geweet het dat Lukas namens hulle berig het of sou berig. Dat so 'n aanname totaal onverdedigbaar en uiters selektief is, het nie bewysvoering nodig nie. Daar kan in die lig van hierdie geval, en ook ander, nie ontken word dat die totstandkoming en geskiedenis van die kerklike belydenisse en belydenisskrifte in verskeie opsigte die resultaat was van teologiese voorkeure en keuses wat vanuit 'n nie-fundamentalistiese hoek as uiters aanvegbaar beskou moet word nie.

Ten slotte moet ook nog daarop gewys word dat die bestaande kerklike belydenisse en belydenisskrifte die lig gesien het gedurende 'n periode in die teologiegeskiedenis van die kerk toe die kerk hom nog volledig vereenselwig het met die wêreldbeskouing van Bybelse tye en toe die historisiteit en daarom die kontingentheid asmede die tendensieusiteit van Bybelse dokumente en tekste nie verdiskonteer is nie. Dit het tot gevolg gehad dat geloofsuitsprake dikwels geïnterpreteer is as verwysend na objektiewe waarhede, dat waarde-oordele as feitestellings aanvaar is, dat bepaalde stemme ten gunste van ander geïgnoreer is, en andersom, en dat die tendensieusiteit van sekere uitsprake of standpunte nie teen hulle agtergronde geëvalueer is nie. Dit behoort vir almal duidelik te wees dat ' $n$ belydenis wat te midde van so 'n wêreld- en Skrifbeskoulike klimaat die lig gesien het, eenvoudig nie meer 'n eietydse waarde en funksie kan hê nie (kyk vir die feit van die kontekstualiteit van belydenisse onder andere Bosman 1987). 


\section{IS 'N BELYDENIS TEKSTEORETIES MOONT- LIK?}

Die feit van die verskeidenheid in die Skrif asmede die genoemde veranderings wat na behoefte in die vroegste geloofsgemeenskappe aan belydenisse aangebring is, is egter net 'n deel van die problematiek waarmee die kerk gekonfronteer staan wanneer dit kom by die opstel van ' $n$ belydenis. 'n Ander het te make met die insigte wat deur die post-strukturale, post-moderne en lesergeoriënteerde denke (om van dekonstruksie en die hermeneutiek van suspisie nie eens te praat nie) in verband met tekste en teksinterpretasie na vore gebring is en waarin daarop klem gelê word dat nie die teks nie, maar die leser bepalend is vir die generering van betekenis en dat daar nie ' $n$ beroep op konsensuskriteria gedoen moet of kan word om tussen verskillende lesings te besluit nie (kyk o a Burnett 1990; Phillips 1990; Adam 1995; en vgl Lategan 1984, 1989; Vorster 1989).

Die bestaande belydenisse het die lig gesien te midde van die benadering dat ' $n$ teks iets is met ' $n$ bepaalde betekenis wat deur interpretasie vasstelbaar is. Uitgaande van die gedagte dat 'n teks 'n "houer" is wat betekenis bevat, word volgens hierdie benadering geoordeel dat dit die taak van die leser is om die "inhoud", die betekenis, uit die houer te tap. Wat meer is, daar word geoordeel dat die houer/teks 'n enkelvoudige entiteit is en dat die inhoud/betekenis ook 'n enkelvoudige entiteit is. Op sterkte hiervan word dan verder geoordeel dat almal behoort saam te stem oor wat die enkelvoudige betekenis van die teks is. Hierdie beskouing oor die aard van 'n teks hou in die eerste plek nie daarmee rekening dat daar in orale kommunikasie nie so iets is as 'n boodskap wat deur 'n medium "vervoer" word nie (kyk Fowler 1985:20; 1991:44). 'n Teks is in 'n sekere sin niks anders as orale kommunikasie wat in skrif gefikseer is nie, natuurlik sonder om hiermee te beweer dat 'n skriftelike en 'n orale teks een en dieselfde ding is en op presies dieselfde wyse kommunikeer.

Die bogenoemde benadering, wat ook nog by die strukturale leesmetodes as uitgangspunt gegeld het, naamlik dat 'n teks sowel as die betekenis daarvan 'n enkelvoudige entiteit is, word vandag eenvoudig nie meer as haalbaar beskou nie. Tereg sê Fowler (1991:3) in hierdie verband: "No longer can meaning be understood to be a stable, determinate content that lies buried within the text, awaiting excavation. Rather, meaning becomes a dynamic event in which we ourselves participate." En Clines 1995:18) stel dit nog sterker wanneer hy sê: “.... it is no crime to say that texts 
mean. It's no crime; it's just not true, properly speaking, that's all". Wanneer ons nie langer kan praat van "die" betekenis van 'n teks as die "inhoud" daarvan nie, kan ons alleen daarvan praat as 'n leeservaring. Hiermee word bedoel dat die lees of interpretasie van 'n teks iets is wat in die tyd plaasvind en waarin die leser in die "proses" van lees betekenis genereer aan die hand van die teks wat gelees word. Om te verduidelik wat hiermee bedoel word, haal Fowler (1985:20) die volgende woorde aan waarmee Iser die leesproses beskryf: "We look forward, we look back, we decide, we change our dicisions, we form expectations, we are shocked by their nonfulfilment, we question, we muse, we accept, we reject; this is the dynamic process of recreation" (my beklemtoning). Betekenis word dus tussen teks en leser in die leesproses geproduseer; dit is nie 'n in-die-teks-voorhande-iets wat daaruit opgediep moet word nie. Daarom word daar in die lesergeorienteerde benadering oor betekenis gepraat in terme van "gebeure" in plaas van "inhoud" (Fowler 1991:47; kyk ook Fish 1980:2-3).

Selfs al sou 'n mens die standpunt wou bly handhaaf dat 'n teks 'n houer is waarin ' $n$ bepaalde betekenis opgesluit lê wat deur interpretasie daaruit opgediep moet word, word 'n mens gekonfronteer met die harde werklikheid van die dikwels uiteenlopende interpretasies wat die resepsiegeskiedenis of Wirkungsgeschichte van tekste opgelewer het, ongeag die vraag of resepsie en Wirkung na dieselfde saak verwys en of eerșgenoemde as lesergeoriënteerd en laasgenoemde as teksgeoriënteerd verstaan moet word (kyk Holub 1984:xi-xii). Van sodanige uiteenlopende interpretasies is die resepsiegeskiedenis van die Bybelse tekste seker die mees uitstaande voorbeeld, iets wat in die geval van religieuse tekste om begryplike redes nie as vreemd beskou hoef te word nie. Wat in elk geval in die eerste plek hieruit duidelik word, is die erkende feit dat alle tekste inherent meerduidig is, al is dit ook onteenseglik waar dat sommiges meerduidiger is as ander. Maar in die tweede plek word hieruit ook duidelik dat verskillende lesers verskillend lees en dat allerlei faktore soos agtergrond, vooronderstellings, ontwikkeling en omstandighede ook nog 'n beslissende rol in die leesproses speel. Dit is om hierdie rede dat daar in die post-moderne benadering tot tekste en die resepsie van tekste geoordeel word dat daar streng gesprokè nie so iets as "die teks" of "die leser" bestaan nie, dat twee mense nooit dieselfde teks lees nie en dat selfs dieselfde leser nie herhaaldelik dieselfde lees nie. Adam gee hiervan 'n raak beskrywing wanneer hy met betrekking tot die post-moderne benadering sê: “... here, a crowd of readers (of whom 'the reader' is at best only the committee chair) 
encounters several different versions of 'the text', which shimmer and shift, chameleonlike, into further different texts" (Adam 1995:19).

'n Mens hoef nie 'n slaafse naprater van hierdie post-moderne beskouings te wees om in te sien dat daar groot waarheid in steek nie. Daar kan inderdaad nie meer gepraat word van "die teks" en "die leser" in ongekwalifiseerde en absolute sin nie en daar kan ook nie meer anders oor die realisering van betekenis gedink word as dat dit iets is wat in 'n wisselwerking tussen teks en leser gegenereer word nie. Verder moet die standpunt dat betekenis tussen teks en leser gegenereer word, gehandhaaf bly ten spyte van die waarheid wat daar mag steek in die kontensie van Fish (1980:14; kyk ook Burnett 1990:54) dat betekenis in werklikheid nie deur of die teks óf die leser gegenereer word nie, maar deur die interpreterende gemeenskap. En al sou dit ook hóé waar wees dat nóg die teks nóg die leser 'n onveranderlike entiteit is, is dit in terme van die vraag na die verstaan van tekste onvermydelik dat steeds van "die teks" en "die leser" gepraat sal en moet word, of hierdie leser dan ook 'n individu of 'n groep is. Maar terwyl dit as 'n uitgemaakte saak beskou kan word dat betekenis iets is wat tussen teks en leser gegenereer word, is daar nie eenstemmigheid onder teksteoretici oor wie van die twee, die teks of die leser, die oorheersende rol hierin speel nie. Sommiges oordeel dat dit die teks is (bv Cooper 1993:14; vgl Combrink 1984), ander dat dit die leser is (bv Fish 1980:13-14; Clines 1995), terwyl dit lyk of die meeste die standpunt huldig dat beide die teks én die leser in gelyke mate en op 'n dialektiese wyse 'n rol hierin speel. "It is not an Either/Or, but a Both/And at best, or a Neither/ Nor at worst" (Wuellner 1989:46; kyk ook Patte 1993; Davidsen 1995:133).

Dit is te begrype dat daar in die meeste gevalle nie aanvaar wil word dat die leser die primêre of uitsluitlike bepaler van betekenis kan of mag wees nie, omdat gevrees word dat tekste dan volledig aan die willekeur van die leser uitgelewer sal wees. Of daar werklik genoeg grond vir hierdie vrees is, is 'n vraag, aangesien daar darem nie enigiets of iets absurds uit 'n teks afgelees kan word, met die aanspraak dat dit om 'n lesing van daardie spesifieke teks gaan nie. Om dit in die woorde van Malbon (1993:99; my beklemtoning) te sê: "We are not free to assume that the text can mean anything just because it can mean many things." Maar al sou ons ook saamstem dat 'n mens nie vry is om enigiets uit 'n teks af te lees nie en dat daar in elke teks, afhangende ook van die aard van die teks, bepaalde leesaanwysers of determinante (constraints) aanwesig is, is dit nog geen waarborg dat almal sal saamstem oor wat as sodanige aanwysers identifiseerbaar is nie, om die eenvoudige rede dat verskillende 
lesers dikwels verskillende determinante in dieselfde teks identifiseer en hulle daardeur laat lei of rig. Hierdie toedrag van sake is daaraan toe te skryf dat die meeste tekste inkoherent is "presenting us not only with multiple organizing patterns but with organizing patterns that are competing, logically inconsistent - with a structure of mutually competing coherences" (Kincaid, in Malbon 1993:99). Fish (1980:13) gaan selfs verder deur te stel dat formele eenhede nie "in die teks" is nie, maar die funksie is van die interpretatiewe model waarvan 'n mens jou in die leesproses bedien. Uiteindelik moet ons eenvoudig insien en toegee dat die leser, of dan die interpreterende gemeenskap, 'n aktiewe en skeppende rol speel in die produsering van betekenis aan die hand van 'n teks, 'n proses waarin die teks nie die alleenbepaler is van wat as betekenis sal realiseer nie. Ons moet verder insien en toegee dat die betekenisse wat van dieselfde teks geproduseer sal word, sal afhang van elke nuwe leser en elke nuwe situasie.

Met die paar opmerkings hierbo in verband met die nuwere beskouings oor tekste asmede die lees en verstaan van tekste het ek nie bedoel om te sê dat 'n belydenis gebaseer op die tekste van die Skrif as prinsipieel onaanvaarbaar of prakties onuitvoerbaar beskou moet word nie. Wat ek hiermee wil betoog, is dat die daarstelling van ' $n$ belydenis gesien moet word as in die eerste plek 'n komplekser aangeleentheid as wat tradisioneel geglo is en dat dit ook nie iets is wat vir tyd en ewigheid as' $n$ afgehandelde saak beskou kan word nie. Ek het vroeër daarop gewvs dat ' $n$ belydenis die neiging het om te verstar tot 'n selfstandige entiteit wat 'n eie lewensloop neem en met die tyd 'n karakter van onveranderlikheid verwerf. Dat hierdie toedrag van sake as onhoudbaar beskou moet word, lyk vir my in die lig van wat hierbo opgemerk is vanselfsprekend, al sou daar ook mense wees wat sal wil teëwerp dat 'n belydenis juis in 'n sekere sin 'n blywende karakter moet hê om te kan dien as 'n simbool waarmee die kerk of die gelowige kan identifiseer. 'n Mens kan trouens om verskeie redes, maar veral op sterkte van hierdie nuwere beskouings, net so goed redeneer dat in plaas daarvan om die getuienis van die Skrif (prakties vir alle tye) in 'n belydenis te wil vasvang, die kerk gewoon hierdie getuienis moet verkondig soos die kerklike eksegese en teologie dit in en vir elke nuwe situasie verstaan. Hierbenewens kan geargumenteer word dat as die kerk die verkondigingstaak ernstig neem, daar nie die nodigheid of behoefte vir ' $n$ belydenis hoef te bestaan nie.

Aan die ander kant kan goeie argumente aangevoer word vir die noodsaaklikheid en plek van 'n belydenis en sal ter ondersteuning hiervan gewys kan word op die 
bekende feit dat daar reeds van die vroegste tye af belydenisse van een of ander vorm en aard in die kerk tot stand gekom het. Die vraag is uiteindelik net wat by die opstel van so ' $n$ belydenis as prinsipiële uitgangspunte moet geld en hoe daar te werk gegaan moet word om dit ' $n$ haalbare onderneming te maak. In hierdie verband kan geredeneer word dat dit heeltemal moontlik is dat daar in 'n bepaalde geloofsgemeenskap tot op groot hoogte konsensus bereik kan word oor beide die teks wat as grondslag vir die belydenis moet dien en oor die verstaan van die betrokke teks. Dit is immers hoe die bestaande kerklike belydenisse tot stand gekom het, hoewel nie een daarvan 'n onkontroversiële ontstaansgeskiedenis gehad het nie.

\section{DIE NOODSAAK VIR DIE EIETYDSHEID VAN 'N BELYDENIS}

Ek vertrou dat ek tot dusver in hierdie studie duidelik genoeg laat blyk het dat dit nie my voorneme was om die daarstelling van 'n nuwe belydenis te beredeneer nie, aangesien dit vir my net gaan oor die vraag of dit noodsaaklik is dat 'n belydenis eietyds moet wees. Wat ter sake is, is dus nie ' $n$ keuse tussen die eietydsmaking van ' $n$ bestaande belydenis of die opstel van 'n nuwe belydenis wat aan die kriterium van eietydsheid sal voldoen nie. Dit gaan oor die vraag na eietydsheid, ongeag of dit ten opsigte van ' $n$ bestaande belydenis uitgemaak moet word of in ' $n$ nuwe belydenis gestalte moet kry.

As ' $n$ mens in aanmerking neem watter funksie ' $n$ belydenis veronderstel is om te verrig, veral gesien teen die agtergrond van die rol wat dit in die vroegste geloofsgemeenskappe vervul het, is daar geen bewysvoering nodig vir die eis dat 'n eventuele belydenis aan die kriterium van eietydsheid móét voldoen nie, en dit in tweërlei opsig, soos reeds hierbo opgemerk. Eerstens moet dit hermeneuties verantwoordbaar wees; tweedens moet dit die gelowige eksistensieel aanspreek. Met hermeneuties verantwoordbaar word bedoel dat so ' $n$ belydenis die resultaat sal wees van ' $n$ interpretasie van die Bybelteks waarin die hele spektrum van hedendaagse hermeneutiese vertrekpunte en wyses van lees verdiskonteer is. Hieronder ressorteer sake soos wêreld- en Skrifbeskouing, die evaluering van die Bybel teen die hele spektrum van die Bybel se historiese agtergrond (familiaal, sosiaal, polities, ekonomies) en alle bruikbare en relevante teorieë oor teks en leser en die rol van die teks en die leser in die verstaansproses. Met die klem wat hier op "hedendaags" gelê word, word na- 
tuurlik nie bedoel dat daar nou vir die eerste keer lig deurgebreek het en dat daar met alle vorige wyses van verstaan totaal by die saak van die Skrif verby gevra is nie, net so min as wat hiermee gesuggereer word dat dit onmoontlik is dat die huidige beskouings en verstaansparadigmas deur ander vervang sal word. Ook word nie gesuggereer dat elke nuwe teorie en praktyk slaafs en onkrities nagevolg moet word nie. Natuurlik moet die geeste telkens op die proef gestel word en moet alles aan strenge wetenskaplike beoordeling onderwerp word. Wat egter vir almal duidelik behoort te wees, is dat daar op talle terreine van menslike denke vir goed van vroeëre beskouings en verstaanswyses afstand gedoen is en moes word en dat 'n mens jou kwalik van teorieë en metodes kan bedien wat agterhaal is. Al moet toegegee word dat die hedendaagse teorieë oor tekste en teksinterpretasie nogal 'n verwarrende prentjie vertoon, is dit nogtans vanselfsprekend dat ' $n$ belydenis wat die produk is van hermeneutiese uitgangspunte en verstaanswyses wat gedurende die ontstaaan daarvan die gangbare was, nie onveranderd gehandhaaf kan word as 'n nuwe verstaansparadigma die teks waarop die belydenis gebaseer is, anders verstaan nie. Die kerk kan derhalwe eenvoudig nie daarmee vrede hê dat daar 'n diskrepansie ontwikkel of bestaan tussen die kerk se belydenis en die kerk se eksegese nie. Dit sal die gevolg hê dat die kerk iets anders sal preek as wat die kerk bely, 'n praktyk wat na my oordeel reeds vir geruime tyd in verskeie opsigte aan die orde van die dag is, of ons dit wil weet of erken of nie.

Neem 'n mens verder die hierbo genoemde realiteit in aanmerking dat dit selfs kan gebeur dat nie net verskillende lesers nie maar selfs dieselfde leser onder veranderde omstandighede en as gevolg van verskillende faktore dieselfde teks verskillend kan lees, dan word dit duidelik hoe relatief en onderhewig aan verandering enige belydenisformule wat op die verstaan van 'n bepaalde teks gebaseer is, kan wees. Hierdie realiteit maak 'n mens net weer daarop bedag dat daar enersyds nie onproblematies daarvan uitgegaan kan word dat ' $n$ teks ' $n$ bepaalde betekenis het wat gewoon daaruit opgediep en in 'n belydenis opgeneem kan word nie en andersyds nie veronderstel kan word dat wat belydend op grond van die teks geformuleer is, beskou moet word as ' $\mathrm{n}$ min of meer finale en vasstaande weergawe van die betekenis van die teks wat voortaan 'n selfstandige lewe as simbool kan voer nie.

Maar nou moet onmiddellik hieraan toegevoeg word dat dit nie beteken dat alles so relatief en onseker is dat ' $n$ mens jou nie meer aan 'n belydenis mag waag nie en dat die daarstelling van ' $n$ belydenis derhalwe as beide prinsipieel en prakties onuitvoerbaar beskou moet word nie. Inteendeel, gelowiges in enige geloofsgemeen- 
skap kan steeds en te eniger tyd besluit om hulle oor hulle geloof belydend uit te spreek en dit dan ook doen met 'n hoë mate van konsensus oor wat as prinsipieel regverdigbaar beskou kan word. Hoe prinsipieel regverdigbaar en uitvoerbaar so 'n onderneming sal wees, sal afhang yan die mate waarin die gemeenskap die eietydse teorie en praktyk van tekskommunikasie en -verstaan krities-evaluerend daarin verdiskonteer het. As daar ook ekumeniese aanvaarbaarheid of konsensus ten opsigte van so ' $\mathrm{n}$ belydenis verkry kan word, is dit natuurlik goed, hoewel so ' $\mathrm{n}$ belydenisvorming nie geprekondisioneer behoort te word deur 'n blote strewe na ekumenisiteit nie.

Net so belangrik as die vereiste dat ' $n$ belydenis hermeneuties eietyds moet wees, is dit dat dit funksioneel eietyds moet wees. Dit wil sê dit moet die rol vervul waarvoor dit daargestel is, en dit geld elke funksie wat dit na die oordeel van ' $n$ bepaalde geloofsgemeenskap veronderstel is om te vervul. Die belangrikste funksie daarvan bly egter die primêre rol wat dit reeds in die geloofslewe van die vroegste Christelike geloofsgemeenskappe vervul het, naamlik dat dit die gelowige in elke lewensituasie eksistensieel moet kan aanspreek en die verwoording moet wees van wat die gelowige hier en nou eksistensieel van haar/sy geloof verstaan en beleef. Enersyds moet dit dus die gelowige telkens in elke nuwe situasie as ' $t$ ware opnuut tot geloof en tot 'n nuwe geloofsbeslissing kan help bring. Andersyds moet dit die gelowige kan help om tot 'n sinvolle, dit wil sê evangeliese, begrip te kom van en 'n greep te kry op haar/sy lewe van elke dag. Maar dan moet dit juis ook aan die gelowige die woorde gee waarmee hy/sy hierdie geloofsgreep op die lewe vir hom-/haarself talig verstaanbaar kan maak. Wat ek nie vir myself talig kan uitdruk nie, kan ek nie 'n begrip van hê nie en kan daarom nie vir my 'n verstaanbare werklikheid of ervaring wees nie. In 'n sekere sin moet 'n belydenis so eksistensieel-eietyds wees dat dit sal doen wat dit sê, dat dit 'n Sprachereignis sal wees soos Paulus dit volgens Romeine 10:9-10 verstaan het. Indien hierdie waarneming korrek is, en ek het die oortuiging dat dit is, behoort dit geen twyfel te laat oor die absolute noodsaaklikheid dat 'n belydenis eietyds moet wees nie. Dit is immers ondenkbaar dat ' $n$ mens jou met ' $n$ belydenis sal kan vereenselwig wat nie verwoord wat jy hier en nou deur die geloof tot jou eie gemaak het of ervaar nie. As ek 'n belydenis waarmee gelowiges gister en eergister uitdrukking aan hulle geloof gegee het, nie meer my eie kan maak deur dit met dieselfde oortuiging as hulle en met oorgawe te herhaal nie, is ek met tradisieverering besig en nie met belydenis nie. Ek moet selfs my eie belydenis van gister 
en eergister ook vandag nog met dieselfde oortuiging en oorgawe kan herhaal om steeds daarvan as $m y$ belydenis te kan praat. En wat van my as individu geld, geld vanselfsprekend in dieselfde mate van die geloofsgemeenskap waarvan ek deel is.

Met dit alles gesê, en as dit waar is, mag 'n mens tot die slotsom kom dat daar dan kwalik sprake kan wees van 'n belydenis as 'n geloofsformulering waarmee gelowiges hulle nie net vandag nie, maar ook môre en oormôre moet kan vereenselwig en tot belewing en uitlewing van sy geloof moet kan kom. So onhaalbaar is die saak egter hoegenaamd nie, aangesien dit volledig moontlik is en ook gebeur het dat geloofsgemeenskappe oor geslagte heen dieselfde belydenis met dieselfde oortuiging en effek kan bely as wat die eerste belyers dit gedoen het. Die eis bly egter steeds dat gelowiges van elke nuwe geslag hulle geloof soos hulle dit verstaan en beleef in so 'n belydenis uitgedruk moet vind, anders kan dit nie as 'n eietydse belydenis beskou word nie. En as 'n mens nie eietyds kan bely nie, bely jy glad nie en het dit tyd geword dat jy jou geloof nuut bely, dat jy jou belydenis eietyds maak.

Dit alles geld natuurlik slegs indien 'n bepaalde geloofsgemeenskap oortuig is van die wenslikheid of noodsaaklikheid van 'n belydenis vir die geloofslewe van daardie gemeenskap. Daar kan egter ook 'n gemeenskap of gemeenskappe van gelowiges wees wat kan besluit om nie 'n geloofsbelydenis te hê nie. Indien wel, moet so 'n gemeenskap se vryheid om so te oordeel, ten volle gerespekteer word.

\section{Literatuurverwysings}

Adam, A K M 1995. What is postmodern Biblical criticism. Minneapolis: Fortress.

Bosman, H L et al 1987. Die Nederlandse Geloofsbelydenis: Ontstaan, Skrifgebruik en gebruik. Pretoria: Universiteit van Suid Afrika. (Instituut vir Teologiese Navorsing.)

Bultmann, R 1968. Theologie des Neuen Testaments. 6. Aufl. Tübingen: Mohr.

Burnett, F W 1990. Postmodern Biblical exegesis: The eve of historical criticism. Semeia 51, 51-80.

Clines, D J A 1995. Varieties of indeterminacy. Semeia 71, 17-28.

Combrink, H J B 1984. Multiple meaning and/or multiple interpretation of a text? Neotestamentica $18,26-37$.

Conzelmann, H 1968. Grundriß der Theologie des Neuen Testaments. 2.Aufl. München: Kaiser. 
Conzelmann, H \& Lindemann, A 1980. Arbeitsbuch zum Neuen Testament. 5.Aufl. Tübingen: Mohr. (UTB 52.)

Cooper, R 1993. Textualizing determinacy./Determining textuality. Semeia 62, 5980.

Davidsen, O 1995. Is there a monkey in the class? Semeia 71, 133-160.

Deichgräber, R 1967. Gotteshymnus und Christushymnus in der frühen Christenheit:

Untersuchungen zu Form, Sprache und Stil der frühchristlichen Hymnen.

Göttingen: Vandenhoeck. (StUNT 5.)

- 1983. s v Formeln, Liturgische. TRE.

Fish, S E 1980. Is there a text in this class? The authority of interpretive communities. Cambridge, MA: Harvard University Press.

Fowler, R M 1985. Who is "the reader" in reader response criticism? Semeia 31, 523.

- 1991. Let the reader understand: Reader-response criticism and the Gospel of Mark. Minneapolis: Fortress.

Holub, R C 1984. Reception theory: A critical introduction. London: Methuen.

Hultgren, A J 1994. The rise of normative Christianity. Minneapolis: Fortress.

Ignatius 1952. Epistula ad Smyrnaeos, The Apostolic Fathers I (with an English trans-

lation by Kirsopp Lake), 251-266. London: William Heinemann Ltd. (LCL.)

Köster, H 1971. Grundtypen und Kriterien früchristlicher Glaubensbekenntnisse, in Köster, H \& Robinson, J M 1971, Entwicklungslinien durch die Welt des frühen Christentums, 191-215. Tübingen: Mohr.

- 1980. Einfuihrung in das Neue Testament im Rahmen der Religionsgeschichte und Kulturgeschichte der hellenistischen und römischen Zeit. Berlin: De Gruyter.

Lategan, B C 1984. Current issues in the hermeneutical debate. Neotestamentica 18, $1-17$.

- 1989. Introduction: Coming to grips with the reader. Semeia 48, 3-17.

Malbon, E S 1993. Texts and contexts: Interpreting the disciples in Mark. Semeia 62, 81-102.

Patte, D 1993. Textual constraints, ordinary readings, and critical exegesis: An androcritical perspective. Semeia 62, 59-80.

Pelser, G M M 1997. Die verhouding verkondiging en belydenis by Paulus. HTS 53(4), 1228-1249. 
Die vraag na die noodsaaklikheid van 'n eietydse belydenis

Phillips, G A 1990. Exegesis as critical praxis: Reclaiming history and text from a postmodern perspective. Semeia 51, 7-50.

Vorster, W S 1989. The reader in the text: Narrative material. Semeia 48, 21-39.

Wegenast, K 1962. Das Verständnis der Tradition bei Paulus und in den Deuteropaulinen. Neukirchen: Neukirchener Verlag. (WMANT 8.)

Wengst, K 1967. Christologische Formeln und Lieder des Urchristentums. Bonn: Rheinische Friedrich-Wilhelm-Universität.

- 1984. s v Glaubensbekenntnis(se). TRE.

Wirsching, J 1980. s v Bekenntnisschriften. TRE.

Wuellner, W 1989. Is there an encoded reader fallacy? Semeia 48, 41-54. 